\title{
Karakteristik dan Upaya Pencegahan Penularan Pada Penderita Tuberkulosis Paru
}

\author{
Mila Triana Sari $^{1}$, Haflin $^{2}$, Dayana Rahmaniyah ${ }^{3}$ \\ ${ }^{1,2,3}$ Departement of Nursing, Baiturrahim School of Health Science \\ Correspondence Email: milatrianasari73@gmail.com
}

\begin{abstract}
Abstrak. Tuberkulosis paru masih menjadi masalah kesehatan prioritas global karena menjadi penyebab kematian terbanyak di dunia untuk penyakit infeksi. Menurut WHO, Indonesia menduduki peringkat ke 3 di dunia setelah India dan Tiongkok. Estimasi kasus tuberkulosis paru di Indonesia tahun 2019, sebanyak 845.000 orang, sedangkan prevalensi penderita tuberkulosis paru sebesar 142 per 100 ribu populasi, Jambi menduduki peringkat ke 5 di Indonesia. Penyakit tuberkulosis paru sangat mudah menular, dan dapat memberikan dampak buruk terhadap anggota keluarga yang tinggal serumah dengan penderita tuberkulosis paru, jika tidak dilakukan upaya pencegahan oleh penderita tuberkulosis paru. Tujuan penelitian ini adalah mengidentifikasi karakteristik dan upaya pencegahan penularan pada penderita tuberkulosis paru. Penelitian ini merupakan penelitian deskriptif, dengan teknik total sampling, dilakukan terhadap 42 orang penderita TB Paru di wilayah kerja PKM Putri Ayu Kota Jambi. Menggunakan instrumen demografi dan pencegahan penularan. Pengumpulandatadilakukan dengan wawancara terpimpin. Hasil penelitian menunjukkan. Usia terbanyak pada penderita tuberkulosis paru adalah usia produktif $(23,8 \%)$ dengan jenis kelamin laki- laki $(57,1 \%)$ pendidikan tertinggi terbanyak adalah pendidikan dasar $(40,5 \%)$ dan pekerjaan adalah IRT $(31,0 \%)$. Sedangkan untuk upaya pencegahan penularan lebih dari setengah $(54,8 \%)$ adalah baik. Diharapkan penderita tuberkulosis paru dapat meningkatkan pengetahuannya terkait pengetahuan penyakit tuberkulosis paru, cara pengobatan dan pencegahan penularan penyakit tuberkulosis paru serta ikut aktif terlibat dalam pemberantasan penyakit tuberkulosis paru, sedangkan petugas puskemas beserta kader dapat melakuan penyuluhan tentang upaya pencegahan penularan tuberkulosis paru untuk meningkatkan pengetahuan masyarakat tentang pencegahan penyakit tuberkulosis paru, serta secara berkala melakukan homevisit ketempat tinggal penderita tubekulosis untuk memantau kondisi penderita tuberkulosis paru.
\end{abstract}

Kata kunci: Karakteristik; Upaya Pencegahan Penularan Tuberkulosis Paru

\begin{abstract}
Pulmonary tuberculosis is still a global priority health problem because it is the leading cause of death in the world for infectious diseases. According to WHO, Indonesia ranks third in the world after India and China. Estimated cases of pulmonary tuberculosis in Indonesia in 2019, as many as 845,000 people, while the prevalence of patients with pulmonary tuberculosis is 142 per 100 thousand population, Jambi ranked 5th in Indonesia. Lung tuberculosis is highly contagious, and can have a devastating effect on family members who live in the same house as people with pulmonary tuberculosis, if prevention efforts are not made by those with pulmonary tuberculosis. The purpose of this study was to identify the characteristics and efforts to prevent transmission in patients with pulmonary tuberculosis. This research is a descriptive study, with a total sampling technique, conducted on 42 people with pulmonary TB in the work area of PKM Putri Ayu Jambi City. Use demographic and transmission prevention instruments. Data collection was carried out by guided interviews. The results showed. The highest age in patients with pulmonary tuberculosis is productive age (23.8\%) with male sex (57.1\%) the highest education is basic education (40.5\%) and employment is IRT (31.0\%). Whereas prevention of transmission for more than half (54.8\%) is good. It is expected that patients with pulmonary tuberculosis can increase their knowledge related to the knowledge of pulmonary tuberculosis, how to treat and prevent pulmonary tuberculosis transmission and to be actively involved in the eradication of pulmonary tuberculosis, while the health center staff and cadres can conduct counseling about efforts to prevent transmission of pulmonary tuberculosis to increase public knowledge about lung tuberculosis eradication, while the health center staff and cadres can conduct counseling about efforts to prevent the transmission of pulmonary tuberculosis prevention of pulmonary tuberculosis, as well as periodically do homevisit to the place of residence of tubulosis patients to monitor the condition of pulmonary tuberculosis sufferers.
\end{abstract}

Keywords: Characteristics; The efforts to prevent transmission of pulmonary tuberculosis

\section{PENDAHULUAN}

Tuberkulosis paru masih menjadi masalah kesehatan prioritas global karena menjadi penyebab kematian terbanyak di dunia. Berdasarkan data World Health Organization (WHO), jumlah kasus baru tuberkulosis paru pada tahun 2015 mencapai 10,4 juta jiwa meningkat dari sebelumnya hanya 9,6 juta Insidens tuberkulosis paling tinggi terdapat di India sebanyak 2,8 juta kasus, diikuti Indonesia sebanyak 1,02 juta kasus (WHO, 2016). Sedangkan prevalensi penderita TBC di
Indonesia pada 2015 sebesar 395 per 100 ribu populasi dengan angka kematian sebesar 40 per 100 ribu populasi serta pada tahun 2016 tuberkulosis paru menjadi penyakit menular yang banyak membunuh dengan angka 274 kematian per hari (INDOPOS, 2016). Prevalensi tuberkulosis paru tahun 2019 berdasarkan data WHO di Indonesia sebesar 845.000 orang (WHO, 2019)

Insidens tuberkulosis paru tertinggi di Indonesia terdapat di Provinsi Banten dan Papua dan insidens tuberkulosis paru terendah terdapat pada Provinsi Babel 
dan Bali. Sedangkan provinsi Jambi menduduki urutan ke-5 penyakit tuberkulosis paru tertinggi di Indonesia (Riskesdas, 2018).

Pencapaian Case Detection Rate (CDR) tuberkulosis paru di Provinsi Jambi pada tahun 2017 Kabupaten/Kota dengan CDR tuberkulosis paru tertinggi terdapat di Kota Jambi dengan prevalensi sebesar $35,15 \%$, dan Kabupaten/Kota dengan CDR terendah terdapat di Kabupaten Kerinci dengan prevalensi sebesar 11,44\%. (Profil Jambi, 2017)

Tuberkulosis paru adalah penyakit yang menular dandapat memberikan dampak buruk terhadap anggota keluarga yang tinggal serumah dengan penderita tuberkulosis paru. Jika tidak dilakukan upaya pencegahan terhadap penderita tuberkulosis paru maka, anggota keluarga yang tinggal serumah dengan penderita akan beresiko tinggi tertularnya penyakit tuberkulosis paru (Rab T, 2010).

Mengingat dampak dari tuberkulosis paru itu sangat beresiko bagi kesehatan maka perlu upaya pencegahan penularan tuberkulosis paru khususnya pada keluarga dan lingkungan terdekatnya,

Menurut Wahid.A (2013) adapun cara untuk mencegahpenyakit tuberkulosis paru adalah dengan cara hidup sehat (makan makanan yang bergizi, istirahat yang cukup, olahraga teratur, hindari rokok, alkohol, hindari stress). Bila batuk mulut ditutup, tidak meludah disembarang tempat, serta lingkungan sehat. Sedangkan pencegahan penularan tuberkulosis paru dirumah yaitu dengan cara tidak berhadapan ketika berbicara, bila batuk mulut ditutup dan tidak meludah disembarang tempat (ludah ditutup tanah atau meludah di tissue dan dibuang ke tempat sampah khusus). Peralatan makanan harus disendirikan, serta ventilasi dan pencahayaan yang cukup terpapar sinar matahari.

Beberapa penelitian yang berkaitan dengan tuberkulosis paru antara lain penelitian Akbar (2016) melaporkan tidak ada hubungan antara pengetahuan dan perilaku pasien tuberkulosis paru dalam pencegahan penularan. Penelitian Rahman (2015) menunjukkan ada hubungan antara pengetahuan dan sikap dengan upaya pencegahan penularan pada masyarakat,sedangkan penelitian Ayurti (2016) melaporkan tidak ada hubungan pengetahuan terhadap prilaku keluarga dalam pencegahan penularan penyakit tuberkulosis paru.

Penelitian ini bertujuan untuk mengidentifikasi karakteristik dan upaya pencegahan penularan pada penderita tuberkulosis paru di Wilayah Kerja Puskesmas Putri Ayu Kota Jambi.

\section{METODE}

Penelitian ini merupakan penelitian Deskriptif, dengan populasi adalah seluruh penderita tuberkulosis paru diwilayah kerja PKM Putri Ayu kota Jambi tahun 2018 sebanyak 52 orang. Pengambilan sampel dilakukan dengan total sampling sebesar 42 orang penderita tuberkulosis paru yang memenuhi kriteria
inklusi.Pengumpulan data karakteristik menggunakan instrumen berupa kuesioner demografi dan upaya pencegahan penularan mengunakan kuesioner yang terdiri dari 14 pernyataan yang dinyatakan valid dan reliabel.

Pengolahan data menggunakan analisis deskriptif dengan persentase, mean, median dan standar deviasi.

\section{HASIL DAN PEMBAHASAN}

Hasil penelitian ini ditampilkan dalam bentuk tabel distribusi frekuensi, dan dianalisis dengan analisis univariat, selanjutnya dapat dilihat pada tabel-tabel dibawah ini:

\section{Karakteristik Demografi}

Tabel 1. Karakteristik Penderita TB Paru Berdasarkan Umur

\begin{tabular}{clcc}
\hline No & \multicolumn{1}{c}{ Umur } & f & \% \\
\hline 1. & $0-5 \mathrm{Thn}$ & 1 & 2.4 \\
2. & $5-11 \mathrm{Thn}$ & 2 & 4.8 \\
3. & $12-16 \mathrm{Thn}$ & 0 & 0 \\
4. & $17-25 \mathrm{Thn}$ & 7 & 16.7 \\
5. & $26-35 \mathrm{Thn}$ & 8 & 19.0 \\
6. & $36-45 \mathrm{Thn}$ & 10 & 23.8 \\
7. & $46-55 \mathrm{Thn}$ & 3 & 7.1 \\
8. & $56-65 \mathrm{Thn}$ & 7 & 16.7 \\
9. & $>65 \mathrm{Thn}$ & 4 & 9.5 \\
\multicolumn{2}{c}{ Total } & 42 & 100.0 \\
\hline
\end{tabular}

Berdasarkan tabel 1 diatas didapatkan hasil bahwa frekuensi penderita tuberkulosis paru berdasarkan umur penderita tuberkulosis paru terbanyak berusia 36-45 tahun yaitu $(23.8 \%)$.

Menurut Harimurti dan Mansjoer (2014) penyakit tuberkulosis paru paling sering ditemukan pada usia muda atau usia produktif (15-50 tahun). Kondisi ini mengancam kesempatan emas indonesia untuk meraih bonus demografi pada 2025 mendatang karena penduduk produktif tersebut tidak bebas dari beban penyakit tuberkulosis paru, untuk itu perlunya deteksi dini dalam menemukan penyakit tuberkulosis paru, memutus rantai penularannya dan mengobati hingga sembuh (Berita satu, 2019).

Faktor umur produktif pada penderita tuberkulosis paru ini dapat mempengaruhi kemampuan dalam meningkatkan dan menerima pengetahuan karena semakin cukup umur maka tingkat pengetahuan dan pola pikir seseorang akan lebih matang dalam berpikir dan menerima informasi. Semakin banyak informasi yang masuk semakin banyak pula pengetahuan yang didapatkan tentang kesehatan seperti informasi tentang penyakit tuberkulosis paru yang merupakan penyakit menular dan beresiko untuk tertular ke anggota keluarga yang tinggal serumah dengan penderita tuberkulosis paru, sehingga berupaya untuk melakukan pencegahan penyakit tuberculosis pada anggota keluarga yang lain. 
Tabel 2. Karakteristik Penderita Tuberkulosis Paru Berdasarkan Jenis Kelamin

\begin{tabular}{|c|c|c|c|}
\hline No & Jenis Kelamin & $\mathbf{f}$ & $\%$ \\
\hline 1. & $\mathrm{~L}$ & 24 & 57.1 \\
\hline 2. & $\mathrm{P}$ & 18 & 42.9 \\
\hline & Total & 42 & 100.0 \\
\hline
\end{tabular}

Berdasarkan tabel 2 diatas didapatkan hasil bahwa frekuensi penderita tuberkulosis paru berdasarkan jenis kelamin penderita tuberkulosis paru terbanyak berjenis kelamin laki-laki (57.1\%).

Menurut Harimurti dan Mansjoer (2014) proporsi penderita tuberkulosis paru kebanyakan berjenis kelamin laki-laki (67\%). Pada jenis kelamin laki-laki penyakit ini lebih tinggi karena pengaruh merokok, tembakau dan dominan mengkonsumsi alkohol sehingga dapat menurunkan sistem pertahanan tubuh dan lebih mudah dipaparkan dengan agen penyebab tuberkulosis paru.

Tabel 3. Karakteristik Penderita Tuberkulosis Paru Berdasarkan Pendidikan

\begin{tabular}{llcl}
\hline \multicolumn{1}{c}{ No } & \multicolumn{1}{c}{ Pendidikan } & f & \multicolumn{1}{c}{$\%$} \\
\hline 1. & Belum sekolah & 1 & 2.4 \\
2. & SD & 17 & 40.5 \\
3. & SMP & 9 & 21.4 \\
4. & SMA & 10 & 23.8 \\
5. & S1 & 5 & 11.9 \\
Total & & 42 & 100.0 \\
\hline
\end{tabular}

Berdasarkan tabel 3 diatas didapatkan hasil bahwa frekuensi pendidikan penderita tuberkulosis paru terbanyak pendidikan SD (40.5\%).

Tingkat pendidikan penderita dominan berpendidikan SD yang menyebabkan pengetahuan penderita mengenai penyakit tuberkulosis paru dalam hal pengenalan penyakit, pengobatan dan upaya pencegahan penularan tuberkulosis paru, masih perlu ditingkatkan.

Penderita banyak yang tidak mengetahui bahwa sumber penularan penyakit tuberkulosis paru adalah penderita tuberkulosis dengan BTA positif, terutama pada waktu batuk atau bersin, penderita menyebarkan kuman ke udara dalam bentuk percikan dahak (droplet nuclei), yang berada dalam ruangan dalam waktu yang lama dan tidak terkena cahaya matahari.

Tabel 4. Karakteristik Penderita Tuberkulosis Paru Berdasarkan Pekerjaan

\begin{tabular}{llcc}
\hline No & \multicolumn{1}{c}{ Pekerjaan } & F & \% \\
\hline 1. & Belum Bekerja & 3 & 7.1 \\
2. & IRT & 13 & 31.0 \\
3. & Mahasiswa & 3 & 7.1 \\
4. & Petani & 7 & 16.6 \\
5. & Buruh & 4 & 9.52 \\
6. & PNS & 3 & 7.1 \\
7. & Wiraswasta & 9 & 21.4 \\
& Total & 42 & 100.0 \\
\hline
\end{tabular}

Berdasarkan tabel 4 diatas didapatkan hasil bahwa frekuensi penderita tuberkulosis paru berdasarkan pekerjaan terbanyak $31.0 \%$ adalah IRT.

Pekerjaan mempengaruhi status ekonomi seseorang, jika status ekonomi menurun penderita tidak mampu untuk mengkonsumsi makanan yang bergizi sebagai upaya dalammeningkatkan daya tahan tubuh dalam melawan Tuberkulosis Paru serta melakukan kontrol ulang ke puskesmas menyebabkan penderita tuberculosis paru tidak rutin mengkonsumsi obat TBdan cendrung untuk drop out sehingga pengobatannya tidak tuntas.

\section{Upaya Pencegahan Penularan Penderita Tuberkulosis Paru}

Tabel 5. Gambaran Upaya Pencegahan Penularan Pada Penderita Tuberkulosis Paru

\begin{tabular}{llcc}
\hline No & Upaya Pencegahan & f & \% \\
\hline 1. & Kurang Baik & 19 & 45.2 \\
2. & Baik & 23 & 54.8 \\
& $\quad$ Total & 42 & 100 \\
\hline
\end{tabular}

Berdasarkan tabel 5 diatas diketahui gambaran upaya pencegahan tuberkulosis paru di Wilayah Kerja Puskesmas Putri Ayu Kota Jambi Tahun 2019, lebih dari setengah penderita tuberkulosis paru $54.8 \%$ memiliki upaya pencegahan tuberkulosis paru yang baik seperti tidak meludah disembarang tempat, tidak merokok di dekat anggota keluarga yang tidak menderita tuberkulosis paru.

Upaya pencegahan yang dilakukan agar terhindar dari penyakit tuberkulosis diantaranya adalah dengan membiasakan pola hidup bersih dan sehat. Selain itu yang dilakukan adalah jika batuk harus menutup mulut dan tidak meludah disembarang tempat, mengisolasikan peralatan makan dan minum penderita, mengurangi hubungan atau komunikasi dengan penderita dan membuka pintu dan jendela setiap pagi.

Upaya pencegahan penularan yang baik merupakan prilaku yang harus ditingkatkan. Notoatmodjo (2007) menyatakan pemberian informasi terhadap seseorang akan meningkatkan pengetahuan orang tersebut, selanjutnya akan menimbulkan kesadaran dalam diri, akhirnya menyebabkan orang tersebut berprilaku sesuai dengan pengetahuan yang dimilikinya.

Hasil penelitian ini sejalan dengan penelitian yang dilakukan oleh Ranchman (2017) dan Fauzie Rahman (2015) yang melaporkan upaya pencegahan penularan tuberkulosis paru berhubungan signifikan dengan pengetahuan.

Petugas kesehatan perlu melakukan pemberian Komunikasi, Informasi dan, Edukasi (KIE) yang dilakukan oleh tenaga kesehatan secara optimal bekerja sama dengan kader kesehatan di desa tentang upaya pencegahan tuberkulosis paru,agar terjadi peningkatan pengetahuan dan keterampilan dalam pencegahan penyakit tuberkulosis sehingga dapat menekan dan 
mencegah penularan penyakit. Disamping itu perlu ditingkatkan kegiatan kunjungan rumah bagi petugas kesehatan untuk mengevaluasi kemampuan penderita terkait keperawatan mandiri penderita penyakit tuberkulosis paru dan mencegah terjadinya penularan tuberkulosis paru.

Selain itu upaya pencegahan dapat juga disebabkan oleh pengaruh orang lain atau kebudayaan dalam pengambilan sikap untuk mencegah terjadinya penularan tuberkulosis paru, sehingga perlu keterlibatan dan dukungan keluarga untuk bersama-sama penderita tuberkulosis paru melakukan upaya pencegahan penularan. Menurut Orem (Taylor, 2006) dukungan keluarga merupakan faktor penting dalam memotivasi penderita tuberkulosis paru, untuk berupaya aktif dalam mengobati penyakitnya dan mencegah penularan tuberkulosis paru.

\section{SIMPULAN}

Penderita tuberkulosis paru yang bertempat tinggal diwilayah kerja PKM Putri Ayu, memiliki karakteristik umur terbanyak pada rentang (36-48 tahun $(23,8 \%)$, jenis kelamin laki-laki $(57,1 \%)$, Pendidikan SD $(40,5 \%)$ dan Pekerjaan IRT $(31,0 \%)$ serta Penderita Tuberkulosis Paru melakukan upaya pencegahan penularan lebih dari setengah baik $(54,8 \%)$.

\section{Saran}

Petugas Kesehatan melakukan penyuluhan, baik melalui Leaflet, ataupun media yang lain serta memberikan bimbingan dan konseling diikuti dengan demonstrasi kepada penderita Tuberkulosis paru dan keluarga untuk meningkatkan pengetahuan dan kemandirian Penderita Tuberkulosis paru dalam pengobatan dan pencegahan penularan.

\section{DAFTAR PUSTAKA}

Akbar,M. Lusiwati, E. Rahayu. 2016. Hubungan Pengetahuan Pasien TBC Dengan Perilaku Pencegahan Penularan Kepada Keluarga Di Puskesmas Sienjo. Dipublikasikan. Diakses tanggal $14 \quad$ Januari 2019.

Melaluhttps://ejournal.bsi.ac.id/ejurnal/index.php/j k/article/view/861

Alsagaff, H. Mukty. 2010. Dasar-Dasar Ilmu Penyakit Paru. Surabaya: Air langga University Press

Ayurti, R. Betan, Y. Goa, Y. 2016. Hubungan Pengetahuandan Sikap Keluarga Dalam Pencegahan Penularan Penyakit Tuberkulosis di Wilayah Kerja Puskesmas Oesapa. Dipublikasikan. Diakses Tanggal 14 Januari 2016. Melalui

cyberchmk.net/ojs/index.php/kesehatan/article/view/28

Chang, E. Daly, J. Elliott, D. 2010. Pathophysiology Applied to Nursing Practice. Yulianti, D. Isneini, S. 2009. Patofisiologi Aplikasipada Praktik Keperawatan. Jakarta: EGC
Data Dinas Kesehatan Kota Jambi. 2018. Penemuan TB Paru. Di Kota Jambi.

Data Profil Jambi Tahun 2017. Pencapaian Case Detectic Rate (CDR) Kasus TB Paru. Di Provinsi Jambi

Data Puskesmas Putri Ayu Kota Jambi. 2018. Berdasarkan Jumlah Kasus Penemuan Kasus Kejadian Tuberkulosis. Puskesmas Putri Ayu Kota Jambi

Depkes RI. 2009. Katagori Umur. Dipublikasikan. Diakses Tanggal 2 Juni 2019 Melaluihttps://yhantiaritra.wordpress.com/2015/0 6/03/kategori-umur-menurut-depkes/

Djojodibroto, D. 2010. Respirologi (Respiratory Medicine). Jakarta: EGC

Hanggraeni, D. 2011. Perilaku Organisasi. Jakarta: Lembaga penerbit Fakultas Ekonomi UI

Harimurti, K. Mansjoer, A. 2014. Naskah Lengkap Penyakit Dalam. Jakarta: Internal Publishing.

Harison. 2013.Buku Saku Pulmonologi. Tanggerang Selatan: Karisma Publising Group

Hidayat, A.A.A 2011. Metode Penelitian Keperawatan dan Teknik Analisa Data. Jakarta: Selemba Medika.

Indopos.co.id Diakses Tanggal 1 Juni 2019 Melalui https://indopos.co.id/read/2018/04/02/133236/keti ka-indonesia-juara-dua-penderita-tbc-terbanyakdi-dunia/

Jainurakhma, J. 2018.Asuhan Keperawatan Sistem Respiratory dengan Pendekatan Klinik. Yogyakarta: Budi Utama

Kementerian Kesehatan RI, 2016. National Strategic Plan of Tuberculosis Control 2016-2020, Jakarta

Kozier, B. Berman. Synder. 2016.Buku Ajar Fundamental Keperawatan Konsep, Proses, \& Praktik. Jakarta: EGC

Manurang, S., Suratun. Krisanty dkk. 2009. Gangguan Sistem Pernafasan Akibat Infeksi. Jakarta: Trans Info Media

Najmah. 2016. Epidemiologi Penyakit Menular. Jakarta: Trans Info Media

Notoatmodjo, S. 2007. Promosi kesehatan dan ilmu prilaku (ed.2). Jakarta. Rineka Cipta

2011. Kesehatan Masyarakat Ilmu \& Seni. Jakarta: Rineka Cipta

2012. Metodologi Penelitian Kesehatan. Jakarta: Rineka 2018. Metodologi Penelitian Kesehatan. Jakarta: Rineka

Nizar, M. 2017. Pemberantasan dan Penanggulangan Tuberkulosis. Yogyakarta: Gosyen Publising

Priyoto. 2014. Teori Sikap dan Perilaku dalam Kesehatan Dilengkapi Contoh Kuesioner. Yogyakarta: Nuha Medika

Rab, T. 2010. Ilmu Penyakit Paru . Jakarta: Trans Info Media

Rachman, Ramdhani Feby. Usep, Abdul, H. Saleh, Trisnadi. Hubungan Tingkat Pengetahuan dan Sikap Masyarakat terhadap Upaya Pencegahan 
Penularan Tuberkulosis di RW 03 Kelurahan Dunguscaring Kota Bandung. Dipublikasikan. Diakses tanggal 14 Januari 2019. Melaluijurnal.unswagati.ac.id/index.php/tumed/ar ticle/view/280

Rahman, F. Adenan. Yulidasari, F. Laily, N. 2015. Pengetahuan dan Sikap Masyarakat Tentang Upaya Pencegahan Tuberkulosis. Dipublikasikan. Diakses tanggal 14 Januari 2019. Melalui journal.unhas.ac.id/index.php/mkmi/article/view/1 993

Riskesdas. 2018. Riset Kesehatan Dasar. Kementrian kesehatan RI, Jakarta

Rizana, N. Tahlil, T. Mulyadi. 2016. Pengaruh, Sikap dan Perilaku Keluarga Dalam Pencegahan Penularan Tuberkulosis Paru. Dipublikasikan. Diakses tanggal 14 Januari 2019. Melalui www.jurnal.unsyiah.ac.id/JIK/article/view/6386

Saryono. 2011. Metodologi Penelitian Kesehatan. Jogjakarta: Mitra Cendikia

Siswanto, A S. 2012. Strategi dan Langkah-Langkah Penelitian. Yogyakarta: Graha Ilmu

STIKBA. 2015. Pedoman Penulisan Skripsi Dan Karya Tulis Ilmiah. Sekolah Tinggi Ilmu Kesehatan Baiturrahim Jambi

Sulistiyana, C. Susanti, S. 2014. Hubungan Pengetahuan dan Sikap Keluarga Pasien Tuberkulosis Parudengan Upaya Pencegahan Penyakit Tuberkulosis Paru di Wilayah Kerja Puskesmas Kesunean dan Pegambiran Kota Cirebon. Dipublikasikan. Diakses tanggal 14 Januari2019.Melaluijurnal.unswagati.ac.id/index. php/tumed/article/view/280

Supardi, S,.Rustika. 2013. Buku Ajar Metodologi Riset Keperawatan. Jakarta: Trans Info Medika Cipta

Sumijatun. 2011. Membudayakan Etika dalam Praktik Keperawatan. Jakarta; Selemba Medika

Taylor S.G (2006) Dorothea E. Orem: Self Care Deficit Theory of nursing. In Nursing Theorists and Their work . pp. 267-296 (6 ${ }^{\text {th }}$ ed). Tomey, A.M and Alligood, M.R. Mosby. St Louis, Missouri.

Videbeck, S. L. 2009. Buku Ajar Keperawatan. Jakarta: EGC

Wahid, A. Suprapto, I. 2013. Asuhan Keperawatan Pada Gangguan Sistem Respirasi. Jakarta: Trans Info Media

Williams. Wikins. Lippincott. 2010. Buku Saku Patofisiologi. Jakarta: EGC

WHO, 2016. Global Tuberculosis report 2016. Geneva, Switzerland: WHO Press

WHO, 2019. Global Tuberculosis report 2019. Geneva, Switzerland: WHO Press 